\title{
JOURNAL.RU
}

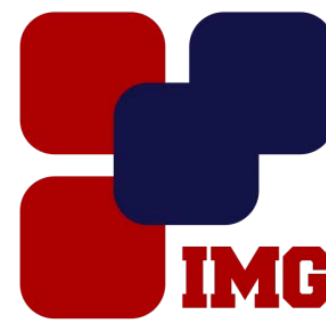

Iyanoy
Management
GaOUP

Шитов С.Б. ФГБОУ ВО «МГТУ «СТАНКИН» Москва, Россия

doi: 10.18411/lj-31-01-2017-3-06

idsp 000001:lj-31-01-2017-3-06

\section{Образование и профессиональная культура современных инженеров (со- циально - философский взгляд)}

Процесс развития современного общества, характеризующийся социальноэкономическими преобразованиями, предъявляет особые требования к личностным качествам человека, т. е. образованию и профессиональной культуре личности. Особую значимость приобретает способность личности ставить и решать новые задачи, находить оригинальные подходы к их решению, выражающиеся в самостоятельности, активности, нестандартности, умению переносить идеи из одной области в другие конкретные условия для реализации целей, способов и средств деятельности.

Обязательным условием эффективного развития современного образования является необходимость повышения уровня социализации обучающихся посредством совместных воспитательных усилий профессорскопреподавательских коллективов с представителями культуры, науки и т. д. [2].

Профессиональная культура специалиста как интегральный показатель творческого начала поведения и деятельности складывается в единстве и взаимодействии всех составляющих:

- системы знаний, убеждений и интересов личности, образующей мировоззренческий уровень, формирующейся на базе интересов, жизненных предпосылок и ценностных ориентаций;

- системы умений и развитых на их основе способностей, образующей уровень практической деятельности, формирующейся на базе социальных потребностей и установок;

- системы индивидуальных норм поведения и освоенных методов деятельности, образующей уровень регуляции социального поведения личности, формирующейся на базе культурных образцов и принципов поведения через различные формы общения и самовоспитания. 
В частности, подготовка современных инженеров должна предполагать не просто их адаптацию к какой-либо новой производственной и др. ситуации, а также современные инженеры должны быть способны изменять ее, при этом изменяясь и развиваясь сами, т. е. основной целью инженерного образования является не усвоение студентом суммы знаний и умений, а овладение профессиональной компетентностью в инженерной деятельности. Сегодня именно инженер как творящий предметный мир становится ключевой фигурой в развитии социально-экономической сферы общества, он должен быть не просто техническим специалистом, решающим узкие профессиональные задачи, а специалистом, который владеет глубокими профессиональными знаниями и способен к творческим действиям «не по шаблону», а инженерное образование становится областью общенациональных стратегических интересов России [1].

Поэтому, воспитывая будущего специалиста в вузе, необходимо заранее ориентировать учебный процесс на профессиональное творчество как область, в которой будущий специалист и после окончания вуза будет продолжать проявлять свою поисковую активность, тем самым обеспечивая себе творческий режим жизни. Поэтому важнейшая задача вуза заключается в создании соответствующих условий для развития творческого потенциала личности [4].

Условия для развития творческого потенциала личности предполагают использование различных технологий обучения.

Например, проблемно-ориентированное обучение позволяет сфокусировать внимание студентов на анализе и разрешении какой-либо конкретной проблемной ситуации, что становится отправной точкой в процессе обучения. При этом иногда важно не столько решить проблему, сколько грамотно ее поставить и сформулировать. Проблемная ситуация максимально мотивирует студентов осознанно получать знания, необходимые для ее решения [3].

Сократический диалог подразумевает активное участие обучающего и обучающегося в обсуждении изучаемого предмета с учетом индивидуального мнения каждого из участников о предмете общения и создания в процессе общения общего смыслового поля. Такие диалогические взаимоотношения благоприятно сказываются на установлении доброжелательного и позитивного настроя, развивают умение слушать и слышать. В связи этим, программа индивидуального развития личности наиболее ориентирует преподавание на помощь субъекту обучения в достижении вершины его возможностей и наиболее полной реализации им потенциала своей личности [5].

Таким образом, формирование и развитие образования и профессиональной культуры личности является важнейшей проблемой и задачей современности, они все в большей степени становятся фактором конкурентоспособности на рынке труда, поэтому обеспечение качественного образования и становления профессиональной культуры является важным фактором развития ресурсов человека и формирования его квалификации. 


\section{Литература}

1. Шитов С.Б. Взаимосвязь высшего технического образования и техносфе-ры в современном обществе как философская проблема // «Вестник МГТУ «СТАНКИН». 2015. - № 2 (33). - С. 119-122.

2. Шитов С.Б. Высшее образование как антитеза молодежного экстремизма (социальнофилософский взгляд) // Alma mater - Вестник высшей школы. - 2016. - № 5. - С. 38-41.

3. Шитов С.Б. Инновационное высшее техническое профессиональное образование: перспективы развития (социально-философский взгляд) // Alma mater - Вестник высшей школы. - 2015.- № 4. - С. 40-44.

4. Шитов С.Б. Подготовка креативных компетентных специалистов-исследователей в обществе знания // Высшее образование сегодня. - 2015. - № 8. - С. 22-25.

5. Шитов С.Б. Учебно-научная деятельность студента как основа личностноориентированного подхода к образованию (социально-философский взгляд) // Alma mater - Вестник высшей школы. - 2016.- № 3. - С. 6-9. 